ISSN 0103-5150

Fisioter. Mov., Curitiba, v. 29, n. 1, p. 71-8, Jan./Mar. 2016

Licenciado sob uma Licença Creative Commons

DOI: http://dx.doi.org.10.1590/0103-5150.029.001.A007

(c) (1)

\title{
Female urinary incontinence: quality of life comparison on reproductive age and postmenopausal period
}

\author{
Incontinência urinária feminina: comparação da \\ qualidade de vida no menacme e pós-menopausa
}

\author{
Mariana Tirolli Rett ${ }^{[a]}$, Érica Brito Wardini ${ }^{[b]}$, Josimari Melo De Santana ${ }^{[\mathrm{a}]}$, \\ Andreza Carvalho Rabelo Mendonça ${ }^{[a]}$, Aline Teixeira Alves ${ }^{[c]}$, Cristina Said Saleme ${ }^{[\mathrm{d}] *}$ \\ [a] Universidade Federal de Sergipe,(UFS), Aracaju, SE, Brazil \\ [b] Fundação Oswaldo Cruz, (FIOCRUZ), Rio Janeiro, RJ, Brazil \\ [c] Universidade de Brasília, (UnB), Brasilia, DF, Brazil \\ [d] Centro Universitário UNA, (UNA), Belo Horizonte, MG, Brazil
}

\begin{abstract}
Introduction: urinary incontinence (UI) is defined as any involuntary leakage of urine and their symptoms can affect women's quality of life (QoL). Objectives: to compare incontinent women's QoLin reproductive age (G1) with those in post menopausal period(G2). Material and methods: a descriptive and retrospective study involved 86 women with UI complaints. Clinical, sociodemographic, obstetrical and gynecological antecedents were collected. Pelvic floor evaluation was conducted by digital palpation and QoL was evaluated by King's Health Questionnaire (KHQ). Mann-Whitney and t Student test were used to compare QoL domains. Results: 36 women in reproductive age (G1) $42.9( \pm 7,4)$ years and 50 women in postmenopausal
\end{abstract}

\footnotetext{
* MTR: PhD, e-mail: mariana@ufs.br EBW: MSc, e-mail: ericawardini@gmail.com JMS: PhD, e-mail: desantanajm@gmail.com ACRM: PhD, e-mail: andrezinharabelo@yahoo.com.br ATA: PhD, e-mail: alinealves@unb.br

CSS: PhD, e-mail: cristinasaleme@gmail.com
} 
period (G2) 61,6 $( \pm 9,3)$ years were assessed. The G2 showed significantly more nocturia $(p=0,0057)$, urge incontinence $(\mathrm{p}=0,0061)$ and enuresis $(0,0021)$ symptoms, whereas in G1 bladder pain and voiding difficulties were more significant. KHQ domains showed statistical differences in: general health perception (G1 26,4 $\pm 16,8$ versus G2 38,0 $\pm 16.2 ; p=0,0019$ ) and emotions (G1 15,1 $\pm 31,3$ versus G2 38,9 $\pm 37,5 ; p=$ 0,0051 ). Conclusion: UI affects negatively QoLin women. Women on postmenopausal period showed higher impact on the QoLdomains related to general health perception and emotions.

Keywords: Urinary incontinence. Quality of life. Pelvic floor. Physical therapy.

\section{Resumo}

Introdução: a incontinência urinária (IU) é qualquer perda involuntária de urina e seus sintomas podem afetar a qualidade de vida (QV) das mulheres. Objetivo: comparar a QV de mulheres incontinentes no menacme e na pós-menopausa. Materiais e métodos: foi realizado um estudo descritivo-retrospectivo envolvendo informações de 86 mulheres com queixas de IU e que foram encaminhadas para tratamento fisioterápico. Foram coletados informações sócio-demográficas, clínicas, antecedentes obstétricos e ginecológicos. A força de contração do assoalho pélvico (AP) foi avaliada pela palpação e a QV avaliada pelo King's Health Questionnaire (KHQ). Foram utilizados o teste de Mann-Whitney e teste $t$ de Student para comparação dos domínios da QV. Resultados: foram selecionadas 36 mulheres no menacme (G1) e 50 na pós-menopausa (G2), com média de idade de 42,9 ( $\pm 7,4$ ) anos e $61,6( \pm 9,3)$ anos respectivamente. $O$ G2 apresentou significativamente mais sintomas de noctúria $(p=0,0057)$, urge-incontinência ( $p=0,0061)$ e enurese noturna $(0,0021)$, enquanto que no G1 foi mais significativa a presença de dor na bexiga e dificuldade para urinar. Entre os domínios do KHQ o G2 apresentou mais comprometimento na percepção geral de saúde G1 26,4 \pm 16,8 versus G2 38,0 $\pm 16,2 ; p=0,0019$ ) e emoções (G1 15,1 $\pm 31,3$ versus G2 38,9 \pm 37,5; $p$ =0,0051). Conclusão: na amostra estudada, a IU afetou negativamente a QV de mulheres no menacme e na pós-menopausa. As mulheres menopausadas demonstraram maior impacto na QV em domínios relacionados com a percepção geral de saúde e as emoções, além da presença de sintomas irritativos como noctúria, urge-incontinência e enurese noturna.

Palavras-chave: Incontinência urinária. Qualidade de vida. Assoalho pélvico. Fisioterapia.

\section{Introduction}

International Continence Society (ICS) and the International Urogynecological Association (IUGA) defines Urinary incontinence (UI) as any involuntary complaint of urine leakage (1). Due to anatomical reasons, hormonal alterations, pregnancies and deliveries consequences, which may compromise pelvic floor muscles, ligaments, fascia and local nerves. Urinary incontinence is more common in women, as a proportion of two women to each man affected $(2,3,4)$. Risk factors as age, obesity, menopause, gynecological surgery, constipation, smoking and low level of physical activity are taken into account to UI development $(4,5,6,7,8)$.

According to ICS and IUGA consensus, the following types of UI could be described: stress urinary incontinence (SUI) is defined as urine leakage during physical exertion, cough or sneeze; urge incontinence (UI) is an urgency associated to involuntary urine leakage which could be caused by a detrusor overactivity during bladder filling; and mixed urinary incontinence (MUI) presents symptoms of both urinary incontinences SUI and UI. There are also: postural UI, continuous UI, insensitive UI and coital UI (1).

UI prevalence varies depending on UI definition, diagnostic method and population surveyed characteristics $(9,10)$. In general, UI affects $19 \%$ of women between 19 and 44 years old, $25 \%$ of women between 45 and 64 years old and $30 \%$ of women above 65 years old (11). SUI is the most common type of UI, affecting younger women between 25 and 49 years old $(10,12,13,14,15)$ while UI and MUI are more prevalent in women above 60 years old.

Urinary symptoms may affect women routine adversely, leading to limitation in physical, social, 
occupational, domestic and sexual activities. The social and hygienic discomfort caused by the fear of: urine lost, urine smell, and the need to use hygienic protectors and clothes changes frequency may affect negatively women quality of life (QoL) $(6,10,17)$. Younger women might have a different life style and physical dynamics compared to the older women, thus hormonal status may interfere on symptoms intensity and, consequently, on their impingement in women routine.

QoL is a concept that involves physical health, psychologic status, independence level, social interaction, personal believes, and their relationship with environment Additional data, such as pelvic floor muscle strength through Modified Brink Scale was assessed (19). Hormonal status classification was obtained through women individual report into two groups: those with regular period were considered on reproductive age and those who have reported amenorrhea for at least 12 months were considered on postmenopausal period. Hence, group 1 (G1) was composed by women on reproductive age and group 2 (G2) was composed by women on postmenopausal period.

QoL evaluation was performed through King-s Health Questionnaire (KHQ), that was translated and validated to Portuguese language (20). It has thirty questions, divided in nine domains: health perception, incontinence impact, daily activities limitation, physical limitation, social limitation, personal relationship, emotions, sleep and energy, and severity measures. There are symptoms scale related to: urinary frequency, nocturia, urge incontinence, detrusor hyperreflexia, stress urinary incontinence, nocturnal enuresis, incontinence during intercourse, urinary infections, and bladder pain. To each answer is given a numeric value, added up and evaluated by domain, thus, as higher the obtained value, lower is QoL (20). The questionnaire was applied by the same investigator, responsible to the study.

Pelvic floor muscle strength was performed with the patient in dorsal decubitus, flexed and abducted hips and knees. The investigator used latex gloves and water soluble gel. Strength was categorized as: 0 (absent); 1 (weak and not sustained contraction, with no movement of the investigator's fingers); 2 (moderate contraction, sustained no more than 3 seconds, with slight movement of the investigator's fingers); 3 (strong contraction, sustained per 3 seconds or more, with movement of the investigator's fingers) $(6,19)$.
Statistical analyses was performed through SPSS software (Statistical Package for Social Science) 12,0. Data analysis include central tendency measures (average), dispersion (standard deviation), relative and absolute frequency. Normality test Shapiro- Wilkwas was applied to evaluate sample distribution. Chisquare and McNemar tests were adopted to categorical variables. Mann-Whitney and Student tests were used to compare QoL evaluation domains.

\section{Results}

One hundred and three women were selected being excluded 17 due to: 1 neobladder, 1 neurological disease, and 15 pregnant women. Among the 86 women referrals, 36 were on reproductive age (G1) average age $42.9( \pm 7.4)$ years old, and 50 were on postmenopausal period (G2) average age $61.6( \pm 9.3)$ years old.

Table 1 shows sociodemographic data, clinical and obstetrical background. Most women in both groups were housewives, married and Caucasian. BMI average on G1 was $26.5 \mathrm{~kg} / \mathrm{m}^{2}$ and on G2 was $26.8 \mathrm{~kg}$ / $\mathrm{m}^{2}$ with no statically difference $(\mathrm{p}=0.3211)$. Most women were multiparous, mainly through vaginal deliveries. Pelvic floor strength did not present significant difference $(\mathrm{p}=0.9318)$ between groups, being grade 1 more frequently (Table 2 ).

Table 1 - Sociodemographic, clinical and obstetrical data background of (Gl) women on reproductive age and on (G2) postmenopausal period

(To be continued)

\begin{tabular}{|c|c|c|c|}
\hline & $\mathrm{Gl}(\mathrm{n}=36)$ & $\mathrm{G} 2(\mathrm{n}=50)$ & $p$ \\
\hline $\begin{array}{l}\text { Age-average } \\
\text { ( } \pm S D)\end{array}$ & $42.9( \pm 7.4)$ & $61.6( \pm 9.3)$ & $\begin{array}{c}< \\
0.0001 a\end{array}$ \\
\hline $\begin{array}{l}\text { BMI -average } \\
( \pm S D)\end{array}$ & $\begin{array}{c}26.5( \pm 5.5) \\
\mathrm{kg} / \mathrm{m} 2\end{array}$ & $\begin{array}{c}26.8( \pm 4.1) \\
\mathrm{kg} / \mathrm{m} 2\end{array}$ & $\begin{array}{c}0 . \\
3211 b\end{array}$ \\
\hline Marital status & $\mathrm{n}(\%)$ & $\mathrm{n}(\%)$ & 0.1484 \\
\hline Married & $25(69.4)$ & $27(54.0)$ & \\
\hline Single / Widow & $11(30.6)$ & $23(43.0)$ & \\
\hline Race & & & 0.1068 \\
\hline Caucasian & $16(44.4)$ & $32(64.0)$ & \\
\hline Otherraces & $20(55.5)$ & $18(36.0)$ & \\
\hline $\begin{array}{l}\text { Level of } \\
\text { education }\end{array}$ & & & 0.0015 \\
\hline
\end{tabular}


Table 1 - Sociodemographic, clinical and obstetrical data background of (Gl) women on reproductive age and on (G2) postmenopausal period

(Conclusion)

\begin{tabular}{lccc}
\hline & & & \\
& $\mathbf{G 1}(\mathbf{n}=\mathbf{3 6})$ & $\mathbf{G} \mathbf{(}(\mathbf{n}=\mathbf{5 0})$ & $\mathbf{p}$ \\
\hline $\begin{array}{l}\text { Incomplete } \\
\text { Elementary } \\
\text { school }\end{array}$ & $9(25.0)$ & $24(48.0)$ & \\
$\begin{array}{l}\text { Complete } \\
\text { Elementary }\end{array}$ & $6(16.7)$ & $17(34.0)$ & \\
school & & & \\
Incomplete & $5(13.9)$ & $2(4.0)$ & \\
High school & & & \\
Complete & $16(44.4)$ & $7(14.0)$ & \\
High scholl & & & \\
Pregnancies & & & 0.0992 \\
Nuliparous & $1(2.8)$ & $2(4.0)$ & \\
Primiparous & $5(13.9)$ & $1(2.0)$ & \\
Multiparous & $30(83.3)$ & $47(94.0)$ & \\
Delivery type & & & \\
Vaginal & $29(80.6)$ & $43(86.0)$ & 0.1828 \\
Cesarean & $11(30.5)$ & $14(28.0)$ & 0.5641 \\
Smokers & $6(16.7)$ & $5(10.2)$ & 0.5157 \\
Constipation & $8(22.2)$ & $18(36.0)$ & 0.699 \\
\hline
\end{tabular}

Note: ${ }^{a}$ Chi-square test, ${ }^{\mathrm{a}}$ Tstudent test, ${ }^{\mathrm{b}}$ Mann Whitney test, $\mathrm{p}<0.05$, Standard deviation (SP).

Source: research database.

Table 2 - Pevic Floor strength of women on reproductive age (G1) and on postmenopausal period (G2)

\begin{tabular}{lcc}
\hline $\begin{array}{l}\text { Pelvic floor } \\
\text { strength grade }\end{array}$ & $\begin{array}{c}\text { G1 }(\mathbf{n}=\mathbf{3 6}) \\
\mathbf{n}(\%)\end{array}$ & $\begin{array}{c}\text { G2 }(\mathbf{n}=\mathbf{5 0}) \\
\mathbf{n}(\%)\end{array}$ \\
\hline Grade 0-Absent & $7(19.4)$ & $7(14.0)$ \\
Grade 1 - Weak & $19(52.8)$ & $28(56.0)$ \\
Grade 2 - Moderate & $8(22.2)$ & $12(24.0)$ \\
Grade 3 - Strong & $2(5.6)$ & $3(6.0)$ \\
\hline
\end{tabular}

Note: a ${ }^{C}$ hi-square test, comparison between groups, $p=0.9318$.

Source: research database.
The most frequent urinary symptoms evaluated by KHQ on G2 were: nocturia ( $p=0,0057)$, urge incontinence $(p=0.0061)$, nocturnal enuresis $(p=0.0021)$. On G1, women reported nocturia, urge incontinence and nocturnal enuresis as a slight or moderated discomfort. The increase of urinary frequency and urgency were also reported commonly as a symptom between groups. More than half of women reported UI as a large discomfort, but there were not significant difference to this symptom. The symptoms less reported were incontinence during intercourse and urinary infections. Bladder pain and difficult to urine were more reported on G1 and presented significant differences between groups (Table 3 ).

Related to KHQ domains, scores of general health perception and emotions were the unique significantly superior on G2 ( $p=0.0019$ and $p=0.0051$ respectively). This is an indicator of greater impairment of these aspects among women on postmenopausal period. Others domains did not present significant difference. However, G2 presented greater scores in incontinence impact, daily activities limitation, sleep and energy, and severity measures. G1 presented discretely greater scores in physical limitation and personal relationships (Table 4).

\section{Discussion}

The study verified that on these sample the presence of urinary symptoms cause negative impact on QoL, independently of women hormonal status or age. UI does not offer imminent risks to women's life, but affect their QoL adversely, interfering in physical, social, occupational, sexual and emotional aspects. Schultz e Kopec (21), in their study about chronic conditions impact on Canadian population, concluded that Alzheimer disease, UI and stroke sequelae affected severally QoL subjects studied. Based on this information, it is possible to understand the relevance of measuring UI effects on women routine.

Table 3 - Urinary symptoms scale by King's Health Questionnaire (KHQ) in women on reproductive age (Gl) and on postmenopausal period (G2)

(To be continued)

\begin{tabular}{lccccc}
\hline & & & & & \\
Urinary symptoms & & Low $\mathbf{n}(\%)$ & Moderate $\mathbf{n}(\%)$ & High $\mathbf{n}(\%)$ & $\mathbf{p}^{\mathbf{a}}$ \\
\hline Frequency & $\mathrm{G} 1$ & $16(44.4)$ & $3(8.3)$ & $14(38.9)$ & 0.1878 \\
& $\mathrm{G} 2$ & $13(26.0)$ & $8(16.0)$ & $27(54.0)$ & \\
\hline
\end{tabular}


Table 3 - Urinary symptoms scale by King's Health Questionnaire (KHQ) in women on reproductive age (Gl) and on postmenopausal period (G2)

(Conclusion)

\begin{tabular}{lccccc}
\hline & & & & & \\
Urinary symptoms & & Low $\mathbf{n}(\%)$ & Moderate $\mathbf{n}(\%)$ & High $\mathbf{n}(\%)$ & $\mathbf{p}^{\mathbf{a}}$ \\
\hline Nocturia & G1 & $10(27.8)$ & $7(19.4)$ & $7(19.4)$ & 0.0057 \\
& G2 & $21(42.0)$ & $17(34.0)$ & $8(16.0)$ & \\
\hline Urinary Urgency & G1 & $11(30.6)$ & $12(33.3)$ & $12(33.3)$ & 0.5088 \\
& G2 & $11(22.0)$ & $13(26.0)$ & $22(44.0)$ & \\
\hline Urge incontinence & G1 & $12(33.3)$ & $10(27.8)$ & $7(19.4)$ & 0.0061 \\
& G2 & $18(36.0)$ & $2(4.0)$ & $22(44.0)$ & \\
\hline Stress incontinence & G1 & $11(30.6)$ & $3(8.3)$ & $19(52.8)$ & 0.2167 \\
& G2 & $7(14.0)$ & $9(18.0)$ & $28(56.0)$ & \\
\hline Nocturnal enuresis & G1 & $3(8.3)$ & $3(8.3)$ & $1(2.8)$ & 0.0021 \\
& G2 & $8(16.0)$ & $3(6.0)$ & $15(30.0)$ & \\
\hline Incontinence during & G1 & $7(19.4)$ & $0(0.0)$ & $5(13.9)$ & 0.0879 \\
intercourse & G2 & $3(6.0)$ & $3(6.0)$ & $4(8.0)$ & \\
\hline Frequent urinary tract & G1 & $2(5.6)$ & $0(0.0)$ & $4(11.1)$ & 0.0675 \\
infection & G2 & $11(22.0)$ & $1(2.0)$ & $8(16.0)$ & \\
\hline Bladder pain & G1 & $15(41.7)$ & $6(16.7)$ & $3(8.3)$ & 0.0273 \\
& G2 & $10(20.0)$ & $3(6.0)$ & $7(14.0)$ & \\
\hline Voiding difficulties & G1 & $8(22.9)$ & $3(8.6)$ & $0(0.0)$ & 0.0024 \\
& G2 & $2(4.5)$ & $0(0.0)$ & $3(6.8)$ & \\
\hline
\end{tabular}

Note: ${ }^{a}$ Chi-square test, $p<0.05$. Source: research database

Table 4 - Scores of quality of life, according to King's Health Questionnaire $(\mathrm{KHQ})$ domains in women on reproductive age (Gl) and on postmenopausal period (G2)

\begin{tabular}{lccc}
\hline & $\begin{array}{c}\text { G1 }(\mathbf{n}=\mathbf{3 6}) \\
\text { Average } \pm \text { SD }\end{array}$ & $\begin{array}{c}\text { G2 }(\mathbf{n}=\mathbf{5 0}) \\
\text { Average } \pm \text { SD }\end{array}$ & $\mathbf{p}$ \\
\hline $\begin{array}{l}\text { General } \\
\text { health } \\
\text { perception }\end{array}$ & $26.4 \pm 16.8$ & $38.0 \pm 16.2$ & 0.0019 \\
$\begin{array}{l}\text { Incontinence } \\
\text { impact }\end{array}$ & $52.8 \pm 28.0$ & $58.7 \pm 32.0$ & 0.3405 \\
$\begin{array}{l}\text { Daily } \\
\text { activities } \\
\text { limitation }\end{array}$ & $16.2 \pm 32.5$ & $30.3 \pm 42.3$ & 0.1484 \\
$\begin{array}{l}\text { Physical } \\
\text { limitation }\end{array}$ & $25.5 \pm 38.1$ & $23.3 \pm 39.6$ & 0.7536 \\
$\begin{array}{l}\text { Social } \\
\text { limitation }\end{array}$ & $10.5 \pm 31.9$ & $10.1 \pm 29.0$ & 0.6790 \\
$\begin{array}{l}\text { Personal } \\
\text { relationship }\end{array}$ & $50.0 \pm 26.6$ & $41.7 \pm 33.3$ & 0.4387 \\
$\begin{array}{l}\text { Emotions } \\
\begin{array}{l}\text { Sleep / } \\
\text { energy }\end{array}\end{array}$ & $15.1 \pm 31.3$ & $38.9 \pm 37.5$ & 0.0051 \\
$\begin{array}{l}\text { Severity } \\
\text { measures }\end{array}$ & $28.9 \pm 21.4$ & $35.9 \pm 23.4$ & $0.1612^{\mathrm{a}}$ \\
\hline
\end{tabular}

Note: Mann-Whitney test, ${ }^{\text {aT }}$ student test, $\mathrm{p}<0.05$
Study sample was homogeneity to sociodemographic, clinical and obstetrical data. There was significant difference only in age. Patients presented overweight in both groups, this is a factor described on previous studies as risk to UI development $(4,12,14-16,22,23,24)$. Multiparity and vaginal delivery, found in G1 and G2, are also considered risk factors to UI and to symptoms severity $(4,8,12,14,16,22,23,25)$.

Women on G2 presented significantly more symptoms of: nocturia, urge incontinence and nocturnal enuresis. It is accept that women on postmenopausal period could report these symptoms more frequently due to estrogenic deprivation and it affects negatively urinary tract (26). Estrogen reduction compromise continence mechanism because of blood reduction flow in urethra and $\alpha$-adrenergic receptors sensibility, resulting in an impairment to the urethral closure pressure. Moreover, it is common among older women irritative symptoms in result of the senility alterations as decrease of bladder capacity, loss of ability to postpone urination, greater difficulty in structural and functional alterations of urethral sphincter face to an involuntary contraction of low magnitude, sleep alteration and associated diseases 
$(16,17,27,28)$. Dedicação et al (28) observed QoL impairment in women with UI between 34 and 85 years old, being those with mixed symptoms who presented worst scores.

In addition, it was verified greater QoL impairment in health perception and emotions domains on G2. General health perception domain describes the perception of patient about her health in the moment and emotions domain describes the feeling of depression and anxiety. Taking in account these domains, it is a hypothesis that irritative symptoms as urge incontinence and nocturnal enuresis, that could not be anticipate by women, may compromise emotionally them, resulting in anxiety.

Moreover, the fact of most women present pelvic floor strength grade 1 involves an impairment of these muscles causing an incapacity to avoid urinary leakage by pelvic floor contraction. It is common to find incontinent women with decreased pelvic floor strength (25). Thereby, this is also a fact involved in UI physiopathology. In agreement with this study, Padrós et al (27) evaluated pelvic floor strength in 92 incontinent women around 60 years old, they conclude that most of women $(65,7 \%)$ presented grade 0 of contraction according to Oxford Scale.

UI domains more affected were sleep and energy, and severity measures. Although scores in G2 were more elevated, there was not significant difference among the domains and groups. Regardless of age, the presence of urinary symptoms affects women routine, sleeps damage and disposition. This occurs due to the need of getting out of bed to go to toilet after sleeping, as well as, the concern about the quantity of ingested liquid. Lopes and Higa (10) observed among 164 women with UI that domestic and occupational restrictions leads to feelings of low self-esteem and social isolation.

Women on reproductive age (G1) presented greater impairment in the domains of physical limitation and personal relationships, though without significant difference. These result might be a consequence of being a younger group with a daily routine frequently with more physical activity, travels, and social activities. Studies report that women with UI on reproductive age present a huge impact in QoL $(6,29,30,31)$.

Related to personal relationships domain, there was not significant difference and scores were similar to scores reported previously in studies $(28,30)$. These item involves aspects of personal and sexual life, as it is less affected, it is probable that women do not talk with their family about urinary leakage problem. This occurs due urinary leakage intensity does not affect the relation with her partner or due to women not have a sexual active life during the study, especially women on postmenopausal period. This could be confirmed in urinary symptoms scale, that normally urinary leakage during sexual relation disturbed only 12 women on G1 and 10 on G2. The data of our study differ from literature data, which report sexual life and partner relationship seriously compromised by the impact of UI in this aspect, as seen in KHQ evaluation (31). Despite of a common condition among women, UI and sexual relation is a subject that causes embarrassment leading to not revealing the problem or treatment searching $(17,29)$

In our study some women reported bladder pain and voiding difficulties, especially in G1. This information is observed in previous studies (31). Perhaps, these symptoms may occur due to the intense routine of younger women with long periods out home and consequently, the need of using public toilet. However, it is not possible to conclude that through our questionnaire.

One limitation of this study is to consider inclusion criteria any clinical complaint of urinary incontinence once no women have performed urodynamic study. This is public health services reality, which is not common to have this as a routine exam. Given the situation, these women were selected through medical referral and were evaluated clinically.

The impact of these symptoms in women life is closely linked to individual perception of severity, type and quantity of urinary leakage and cultural context where this women are inserted. In consequence of UI discomfort women routine assessment should considered QoL in clinical practice. QoL will be increasingly a central parameter to guide, to support and to justify therapeutic interventions. These information are useful to delineate prevention strategies and integral and humanized treatment to reduce UI impact in different aspects of QoL. Therefore, the health professional should always be careful to guarantee self-esteem and to decrease negative aspects of UI in personal, physical and social relations, independently of patient hormonal status.

\section{Conclusion}

UI affects negatively QoL of women on reproductive age as on postmenopausal period. There is a 
significantly higher impact of UI in postmenopausal women Qol especially on the following domains: general health perception and emotions, besides symptoms as nocturia, urge incontinence, and nocturnal enuresis.

\section{References}

1. Haylen BT, Ridder D, Freeman RM, Swift SE, Berghmans B, Lee J et al. An International Urogynecological Association (IUGA) / International Continence Society (ICS) joint report on the terminology for female pelvic floor dysfunction. IntUrogynecol J. 2010; 21:5-26.

2. Simeonova Z, Milson I, Kullendorf AM. The prevalence of urinary incontinence and its influence on the quality of life in women from urban Swedish population. ActaObstGynecol Scand. 1999;78(6):546-51.

3. Peyrat L, Haillot O, Bruyere F, Boutin JM, Bertrand $P$; Lanson Y. Prevalence and risk factors of urinary incontinence in young and middle-aged women. BJU International. 2002;89:61-6.

4. Foldspang A, Mommesen S, Lam GW, Elving L. Parity as a correlate of adult female urinary incontinence prevalence. J Epidemiol Community Health. 1992;46(6):595-600.

5. Rett MT, Simoes JA, Herrmann V, Pinto CL, Marques AA, Morais SS. Management of stress urinary incontinence with surface electromyographyassisted biofeedback in women of reproductive age. PhysTher. 2007;87:136-42.

6. Steinauer JE, Waetjen LE, Vittinghoff E, Subak LL, Hulley SB, Grady D, et al. Postmenopausal hormone therapy: does it cause incontinence? Obstet Gynecol. 2005; 106:940-5.

7. Sakondhavat C, Choosuwan C, Kaewrudee S, Soontrapa S, Louanka K. Prevalence and risk factors of urinary incontinence in KhonKaen menopausal women. J Med Assoc Thai. 2007; 90(12):2533-57.

8. Anger JT, Saigal C, Litwin M. The prevalence of urinary incontinence among community dwelling adult women: results from the National Health and Nutrition Examination Survey. J Urol. 2006; 175(2):601-4.

9. Lopes MHB, Higa R. Restrições causadas pela incontinência urinária à vida da mulher. Rev Esc Enferm. 2006; 40(01):34-41.
10. Shamliyan TA, Kane RL, Wyman J, Wilt TJ. Systematic review: randomized, controlled trials of nonsurgical treatments for urinary incontinence in women. Annals Int Med. 2008; 148(6):459-74.

11. Hannestad Y, Rortveit G, Daltveit AK, Hunskaar S. Are smoking and other lifestyle factors associated with female urinary incontinence? Br J ObstetGynaecol. 2003;110 (3):247-54.

12. Minassian VA, Drutz HP, Badr AL. A. Urinary incontinence as a worldwide problem. IntJGynecol Obstet. 2003;82(3):327-38.

13. Higa R, Lopes MHBM. Fatores associados com a incontinência urinária na mulher. Rev Bras Enferm. 2005;58(4):422-8.

14. Dellú MC, Zácaro PMD, Schmitt ACB. Prevalência de sintomas urinários e fatores obstétricos associados em mulheres adultas. Rev Bras Fisioter. 2008; 12 (6): 482-7.

15. Brown JS, Grady D, Ouslander JG, Herzog RA, Verner E, Posner SF. Prevalence of urinary incontinence and associated risk factors in postmenopausal women. Obstet and Gynecol. 1999;94(1):66-70.

16. Saleh N, Bener A, Khenyab N, Al-Mansori Z, Al-Muraikhi A. Prevalence, awareness and determinants of health care-seeking behaviour for urinary incontinence in Qatari women: a neglected problem? Maturitas. 2005;50(01):58-65.

17. Rett MT, Giraldo PC, Gonçalves AKS, Eleutério Junior J, Morais SS, DeSantanaJM, Amaral RLG. Short-term physical therapy treatment for female urinary incontinence: a quality of life evaluation. Urol Int. 2014; 93 (1): 235-9.

18. The World Health Organization Quality of Life assessment (WHOQOL): position paper from the World Health Organization. Social Sciense and Medicine. 1995;41 (10):1403-9.

19. Brink CA, Wells J, Sampselle CM, Taillie ER, Mayer R. A digital test for pelvic muscle strength in women with urinary incontinence. Annual Review of Nursing Research. 1994;43(6):352-6.

20. Tamanini JTN, D'ancona CAL, Botega JN, Junior NRN. Validação do "King's Health Questionnaire" para o português em mulheres com incontinência urinária. Rev SaúdePública. 2003;37:203-211. 
21. Schultz SE, Kopec JA. Impact of chronic conditions. Health Reports. 2003;14(4):41-53.

22. Guarisi T, Neto AMP, Osis MJ, Pedro AO, Paiva LHC, Faúndes A. Incontinência urinária entre mulheres climatéricas brasileiras: inquérito domiciliar. Rev Saúde Pública. 2001;35(5):428-435.

23. Subak LL, Wing R, West D, Delia S. Weight loss to treat urinary incontinence in overweight and obese women. The New England Journal of Medicine. 2009; 360(5):481-490.

24. Martin DG, Silveira L, Zerwes EP, Roth MGM. Avaliação da força muscular e ativação pressórica do assoalho pélvico de mulheres climatéricas com incontinência urinária de esforço. Fisioter Bras. 2010;11(1):122-127.

25. Steinauer JE, Waetjen EL, Vittinghoff E, SubakL,Hulley SB, Grady D, et al. Postmenopausal hormone therapy: does it cause incontinence? Obstet Gynecol. 2005;106(5):940-945.

26. Padros J, Peris T, Salva A, Denkinger MD, Coll-Planas L. Evaluation of a urinary incontinence unit for community-dwelling older adults in Barcelona: Implementation and improvement of the perceived impact on daily life, frequency and severity of urinary incontinence. Z Gerontol Geriatr. 2008;41:291-297.
27. Dedicação AC, Haddad M, Saldanha MES, Driusso P. Comparação da qualidade de vida nos diferentes tipos de incontinência urinária feminina. Rev Bras Fisioter. 2009;13(2):116-122.

28. Fultz NH, Burgio K, Diokno AC, Kinchen KS, Obenchain $\mathrm{R}$, Bump RC. Burden of stress urinary incontinence for community-dwelling women. Am J Obstet Gynecol. 2003;189 (5):1275-1282.

29. Stach-Lempinen B, Kirkinen P, Laippala P, Metsanoja $\mathrm{R}$, Kujansuu E. Do objective urodynamic or clinical findings determine impact of urinary incontinence or its treatment on quality of life? Urology. 2004;63(1):67-71.

30. Rett MT, Simoes JA, Herrmann V, Gurgel MSC, Morais SS. Qualidade de vida em mulheres após tratamento da incontinência urinária de esforço com fisioterapia. Rev Bras Ginecol Obstet. 2007; 29(3):134-40.

Recebido: 28/02/2013

Received: 02/28/2013

Aprovado: 26/06/2015

Approved: 06/26/2015 